\title{
Overcoming strawberry achene dormancy for improved seedling production in breeding programs
}

\author{
Superación de la latencia de los aquenios de la fresa para mejorar la producción de \\ plántulas en programas de mejoramiento
}

\author{
Alexandre Gonçalves Galvão ${ }^{1 *}$, Luciane Vilela Resende ${ }^{1}$, Renato Mendes Guimaraes ${ }^{1}$, \\ Andrew Kim Lopes Ferraz ${ }^{1}$, Rafael Gustavo Ferreira Morales ${ }^{2}$, Josué Clock Marodin ${ }^{3}$, \\ Hugo Cesar Rodrigues Moreira Catão ${ }^{1}$
}

\begin{abstract}
Strawberry achenes present tegument dormancy. This fact, together with the low efficiency of artificial pollination requires a larger number of crossings to ensure the minimum number of achenes used in seedling production in breeding programs. The aim of this study was to test chemical solutions to overcome dormancy in strawberry achenes in order to increase the germination and Germination Speed Index (GSI). The study consisted of two experiments. 1) immersion in $\mathrm{H}_{2} \mathrm{SO}_{4}(98 \%), \mathrm{HCl}(37 \%)$ and $\mathrm{NaClO}$ (2\%) for 0 (control), 10, 20, 35 and 50 min were evaluated. 2) achenes were immersed in $\mathrm{H}_{2} \mathrm{SO}_{4}(98 \%)$ for 0 (control), 20, 25, 30, 35 and $40 \mathrm{~min}$. A completely randomized design with four replications was used. Germination and GSI were assessed daily for 15 days. Scarification with $\mathrm{H}_{2} \mathrm{SO}_{4}(98 \%)$ for 40 min increased strawberry achene germination to $80 \%$ and can be used as a technique to overcome dormancy. Scarification with $\mathrm{HCl}$ and $\mathrm{NaClO}$ increases germination and the GSI, however, other concentrations and immersion times of those methods should be studied.
\end{abstract}

Key words: fragaria x ananassa Duch, strawberry breeding, tegumentary dormancy, acid scarification

\section{RESUMEN}

Los aquenios de la fresa presentan latencia del tegumento. Este hecho, unido a la baja eficiencia de la polinización artificial implica en la realización de un mayor número de cruzamientos para asegurar el número mínimo de aquenios utilizados en la producción de plántulas en programas de mejoramiento. El objetivo de este estudio fue el de probar soluciones químicas para superar la latencia en aquenios de la fresa con el fin de aumentar la germinación y el índice de velocidad de germinación (IVG). Este estudio consistió en dos experimentos. 1) Inmersión en $\mathrm{H}_{2} \mathrm{SO}_{4}(98 \%), \mathrm{HCl}$ (37\%) y $\mathrm{NaClO}(2 \%)$ para los tiempos de $\mathrm{O}$ (control), 10, 20, 35 y 50 minutos. 2) los aquenios se sumergieron en $\mathrm{H}_{2} \mathrm{SO}_{4}$ (98\%) para los tiempos de 0 (control), 20, 25, 30 , 35 y 40 minutos. Se utilizó un diseño completamente al azar (DCA) con cuatro repeticiones. La germinación y el IVG fueron evaluados todos los días durante 15 días. La escarificación con $\mathrm{H}_{2} \mathrm{SO}_{4}$ (98\%) durante 40 min aumenta la germinación de los aquenios de la fresa a $80 \%$ y puede ser utilizado como una técnica para superar la latencia. La escarificación con HCl y NaClO aumenta la germinación y el IVG, sin embargo, debe estudiarse junto a otras concentraciones y tiempos de inmersión de esos métodos.

Palabras clave: fragaria x ananassa Duch, mejoramiento de la fresa, latencia tegumentaria, escarificación con ácido.

\section{Introduction}

The strawberry is considered the most widespread crop in the world among small fruits. Its cultivation is possible in countries with temperate, subtropical and even tropical climates in areas of high altitude. The strawberry is highly valued in many nations due to its great characteristics of aroma, appearance and flavor. It has low calorie values but is high in fiber, vitamin $\mathrm{B} 9$, vitamin $\mathrm{C}$ and many other antioxidants (Chandler et al., 2012; Folta \& Davis, 2006).

The high demand for strawberries in the last decade represented a major increase in the rate of consumption among the small fruits (FAO, 2013). Following this trend, a continued increase

\footnotetext{
Universidade Federal de Lavras, UFLA, Lavras, MG, Brasil. Caixa Postal 3037, CEP 37200-000.

Empresa de Pesquisa Agropecuária e Extensão Rural de Santa Catarina-EPAGRI, Itajaí, SC, Brasil.

Universidade Estadual do Centro-Oeste do Paraná, Unicentro, Guarapuava, PR, Brasil.

* Autor para correspondencia: galvao.alexandre@posgrad.ufla.br
}

Fecha de Recepción: 25 Junio, 2014.

Fecha de Aceptación: 5 Septiembre, 2014. 
of production, selling price and consumption of strawberries is expected (Qin et al., 2008).

Due to this growing demand, breeding programs to obtain better plants in various aspects are needed. One of the first steps in a strawberry breeding program is to obtain plants originated from achenes. Despite being apparently simple, this phase is one of the biggest hurdles to overcome, as the achene presents tegument dormancy, which reduces the percentage of germination and may cause loss of potentially valuable genotypes, since each achene has the potential to generate genetically superior plants (Miller et al., 1992).

Low efficiency of artificial pollination is another major factor which results in few pollinated achenes per fruit. This fact, together with the low percentage of germination of achenes, requires making a larger number of crossings to ensure the minimum number of seeds used in breeding programs. Achieving achene germination above $70 \%$ within 15 days after sowing would increase the efficiency of obtaining seedlings in strawberry breeding programs.

Several researchers have worked with seed treatment in different types of chemical solutions to overcome tegumentary dormancy in many species. Tegumentary dormancy can be overcome with the aid of scarification, a term that refers to any treatment that results in weakening or rupture of the seed tegument, allowing water permeability which favors germination (Mayer \& Poljakoof-Mayber, 1989). Promising results were obtained with the use of sodium hypochlorite $(\mathrm{NaClO})$ (Erasmo, et al., 2008; Wada \& Reed, 2011), hydrochloric acid (HCl) (Durrant et al., 992, Miller et al., 1992) and sulfuric acid $\left(\mathrm{H}_{2} \mathrm{SO}_{4}\right)$ (El Hamdouni et al., 2001, Ito et al., 2011, Scoot \& Ink, 1948). In the case of strawberries various treatments have been tested, such as cold treatment (Thompson, 1969), light exposure (Nakamura, 1972), cuts on the achenes (Miller \& Chandler, 1990) and acid scarification (Ito et al., 2011). However, little is known about the action of chemical scarification by $\mathrm{NaClO}$, $\mathrm{HCl}$ and $\mathrm{H}_{2} \mathrm{SO}_{4}$.

Thus for efficient propagation of strawberries from achenes it is necessary to develop alternative methods that increase the germination percentage and hence the efficiency of seedling production. The aim of his study was to test chemical solutions to overcome dormancy in strawberry achenes, to increase the percentage of germination and the germination speed index.

\section{Material and methods}

The experiments were conducted at the Laboratory of Seed Analysis of the Department of Agriculture, Federal University of Lavras - UFLA between April and May, 2013.

Achenes of the cultivar Aromas were obtained at the Federal University of Lavras-MG, from fruits harvested in two periods (January and February 2013); each period was considered a batch. The achenes were extracted from the central region of fully ripe fruits, with the aid of a blender for extracting seeds (Osterizer Mod 4655). The achenes were stored in a desiccator $\left(25^{\circ} \mathrm{C}\right)$ for two days before the beginning of the first experiment and 15 days before the second experiment.

The study consisted of two experiments. First, the effects of the following pre-germination treatments to overcome dormancy of two batches of achenes were evaluated: immersion in $\mathrm{H}_{2} \mathrm{SO}_{4}$ (98\%); immersion in $\mathrm{HCl}(37 \%)$ and immersion in $\mathrm{NaClO}(2 \%)$. Achenes were immersed in each chemical solution for 0 (control), 10, 20, 35 and $50 \mathrm{~min}$. In the treatments, a glass rod was used manually to stir the solutions constantly. After the treatments seeds were washed in running water three times to remove the solutions.

Cleansing of all seeds was done in $\mathrm{NaClO}(2 \%)$ for $10 \mathrm{~min}$. Finally, the seeds were again washed three times in running water. In order to eliminate possible differences due to soaking, the not scarified (control) achenes were also immersed in water at the same time as the treatments. The germination test was conducted in a completely randomized design with four replications. Each replication consisted of an acrylic gerbox previously disinfected with ethanol (70\%), two overlapping sheets of Germitest ( ${ }^{\circ}$ paper moistened with distilled water equivalent to 2.5 times the weight of the paper (Brasil, 1992) and 50 achenes placed on the upper surface of the sheets. The achenes were maintained in a BODtype germination chamber with a temperature of 24- $26^{\circ} \mathrm{C}$ and a photoperiod of $16 \mathrm{~h}$. Evaluation of germination was performed daily for 15 days. The achenes that showed radicle protrusion with $\pm 1 \mathrm{~mm}$ length, measured using a magnifying glass, were considered germinated. The achenes considered germinated were removed after each evaluation.

The methodology proposed by Maguire (1962) to calculate the germination speed index (GSI) uses the following equation: 
$\mathrm{GSI}=\mathrm{G}_{1} / \mathrm{N}_{1}+\mathrm{G}_{2} / \mathrm{N}_{2}+\ldots \mathrm{G}_{\mathrm{n}} / \mathrm{N}_{\mathrm{n}}[1]$; where $\mathrm{G}_{1}$, $\mathrm{G}_{2}, \ldots \mathrm{G}_{\mathrm{n}}=$ number of normal seedlings counted in $\mathrm{n}$ steps and $\mathrm{N}_{1}, \mathrm{~N}_{2}, \ldots \mathrm{N}_{\mathrm{n}}$ = number of days from sowing in $\mathrm{n}$ counts.

The remaining achenes of two batches, which were stored in a desiccator for 15 days, were used to perform the second experiment. The achenes were immersed in $\mathrm{H}_{2} \mathrm{SO}_{4}(98 \%)$ for 0 (control), 20, 25, 30, 35 and $40 \mathrm{~min}$. The procedures for stirring, washing and disinfecting achenes were performed as described in the first experiment.

The results were first submitted to a normality test (Shapiro-Wilk) and subsequently analyzed by analysis of variance $(\mathrm{P} \leq 0.05$ and 0.01$)$, polynomial regression and Person correlation ( $\mathrm{t}$ test $\mathrm{P} \leq 0.05$ and 0.01). The results of the germination and GSI comparison between the solutions and between batches were compared using a Tukey test $(\mathrm{P} \leq$ 0.05 and 0.01 ). The results of germination and GSI for different immersion times in the solutions were subjected to polynomial regression. In the regression analysis, polynomial models of first and second order were tested. When the data were adjusted to a second-order polynomial model, the equation was derived to obtain the points of maximum and minimum.

\section{Results and discussion}

There was no interaction between the variables studied in the first experiment, except for chemical solutions $\mathrm{x}$ time (Table I). There was interaction between batch $\mathrm{x}$ time in the second experiment. There were significant mean differences for all variables by the Tukey test in both experiments. There was a positive correlation between germination and GSI for both experiments $\left(0.978 * *\right.$ and $0.985^{* *}$ experiment 1 and 2, respectively) indicating a direct influence on the germination of strawberry achene GSI.

Considering the overall mean, in the first experiment achene immersion in $\mathrm{H}_{2} \mathrm{SO}_{4}$ produced the highest germination (43\%) and the highest GSI (3.787) among treatments (Table II). The $\mathrm{NaClO}$ and $\mathrm{HCl}$ solutions promoted less than $10 \%$ germination; the germination rate in the absence of treatment was $3 \%$. Germination percentage and GSI of batch 2 was greater than batch 1 in both experiments, indicating that the percentage and germination speed are variable between samples and/or batches of achenes, as previously reported by Ito et al., (2011).

Analyzing treatments by times the lowest germination (3.33\%) was observed in the control (0 $\mathrm{min})$, which indicates that there is need of treatment to overcome dormancy (Figure I). Immersion of achenes in $\mathrm{H}_{2} \mathrm{SO}_{4}$ increased germination, with the maximum after $38 \mathrm{~min}$ (batch $1=67 \%$ and batch 2 $=70 \%$ ) and a slight reduction in germination after that immersion time (Figure I A and B, respectively).

Treatments by immersion of achenes in $\mathrm{HCl}$ and $\mathrm{NaClO}$ linearly increased germination of achenes, however, these treatments were less effective in increasing germination compared to $\mathrm{H}_{2} \mathrm{SO}_{4}$. Therefore

Table I. Germination and GSI Summary of analysis of variance of two batches of strawberry achenes Aromas cv., undergoing chemical scarification.

\begin{tabular}{|c|c|c|c|c|c|c|}
\hline \multirow{3}{*}{ Source } & \multirow{3}{*}{ DF } & \multicolumn{2}{|c|}{ Exp I } & \multicolumn{3}{|c|}{ Exp II } \\
\hline & & \multicolumn{2}{|c|}{ Mean Square } & \multicolumn{3}{|c|}{ Mean Square } \\
\hline & & Germination & GSI & DF & Germination & GSI \\
\hline Batch & 1 & $149.511^{* *}$ & $0.964^{* *}$ & 1 & $102.083^{*}$ & $1.867^{*}$ \\
\hline Time & 4 & $2549.155^{* *}$ & $26.492^{* *}$ & 5 & $8354.283^{* *}$ & $77.508^{* *}$ \\
\hline Chem. Sol. & 2 & $12683.377^{* *}$ & $119.937^{* *}$ & & & \\
\hline $\mathrm{CS} \times \mathrm{Ti}$ & 8 & $1526.822^{* *}$ & $21.388^{* *}$ & & & \\
\hline Bat x Ti & 4 & $8.622^{\mathrm{ns}}$ & $0.114^{\mathrm{ns}}$ & 5 & $8.683^{*}$ & $1.051^{*}$ \\
\hline Bat x CS & 2 & $14.044^{\mathrm{ns}}$ & $0.095^{\text {ns }}$ & & & \\
\hline Bat x CS x Ti & 8 & $6.489^{\mathrm{ns}}$ & $0.101^{\mathrm{ns}}$ & & & \\
\hline Error & 60 & 9.467 & 0.056 & 36 & 18.694 & 0.242 \\
\hline $\mathrm{CV}(\%)$ & & 16.16 & 16.07 & & 7.56 & 10.15 \\
\hline
\end{tabular}

Exp: Experiment; Chem. Sol.: Chemical Solutions (CS); Ti: Time; Bat: Batch; GSI: Germination Speed Index; ${ }^{\text {ns}}$ : not significant; ${ }^{*},{ }^{* *}$ Significant at the $\mathrm{P}<0.05$ and $\mathrm{P}<0.01$ level, respectively. 
Table II. Percentage and germination speed index (GSI) of two batches of strawberry achenes Aromas cv., undergoing chemical scarification.

\begin{tabular}{|c|c|c|c|c|c|c|c|}
\hline \multicolumn{8}{|c|}{ Experiment I } \\
\hline \multicolumn{4}{|c|}{ Germination } & \multicolumn{4}{|c|}{ GSI } \\
\hline Batch & $\%$ & Chemical Sol. & $\%$ & Batch & \multicolumn{3}{|c|}{ Chemical Sol. } \\
\hline & & Control & $3.33 \mathrm{~d}$ & & & Control & $0.125 \mathrm{c}$ \\
\hline 1 & $17.73 \mathrm{~b}$ & $\mathrm{NaClO}$ & $5.40 \mathrm{c}$ & 1 & $1.377 \mathrm{~b}$ & $\mathrm{NaClO}$ & $0.238 \mathrm{c}$ \\
\hline 2 & $20.35 \mathrm{a}$ & $\begin{array}{r}\mathrm{HCl} \\
\mathrm{H}_{2} \mathrm{SO}_{4}\end{array}$ & $9.06 \mathrm{~b}$ & 2 & $1.584 \mathrm{a}$ & $\mathrm{HCl}$ & $0.416 b$ \\
\hline \multicolumn{4}{|c|}{$\mathrm{CV}=16.16 \%$} & \multicolumn{3}{|c|}{$\mathrm{CV}=16.07 \%$} & \\
\hline \multicolumn{8}{|c|}{ Experiment II } \\
\hline \multicolumn{4}{|c|}{ Germination } & \multicolumn{4}{|c|}{ GSI } \\
\hline \multicolumn{2}{|r|}{ Batch } & \multicolumn{2}{|c|}{$\%$} & \multicolumn{3}{|c|}{ Batch } & \\
\hline & 1 & \multicolumn{2}{|c|}{$55.75 \mathrm{~b}$} & & 1 & \multicolumn{2}{|c|}{$4.651 \mathrm{~b}$} \\
\hline & 2 & & & & 2 & & \\
\hline \multicolumn{4}{|c|}{$\mathrm{CV}=7.56 \%$} & \multicolumn{4}{|c|}{$\mathrm{CV}=10.15 \%$} \\
\hline
\end{tabular}

Means followed by the same lowercase letter in the column do not differ among themselves by the Tukey test $(\mathrm{P}<0.05$ and 0.01$)$
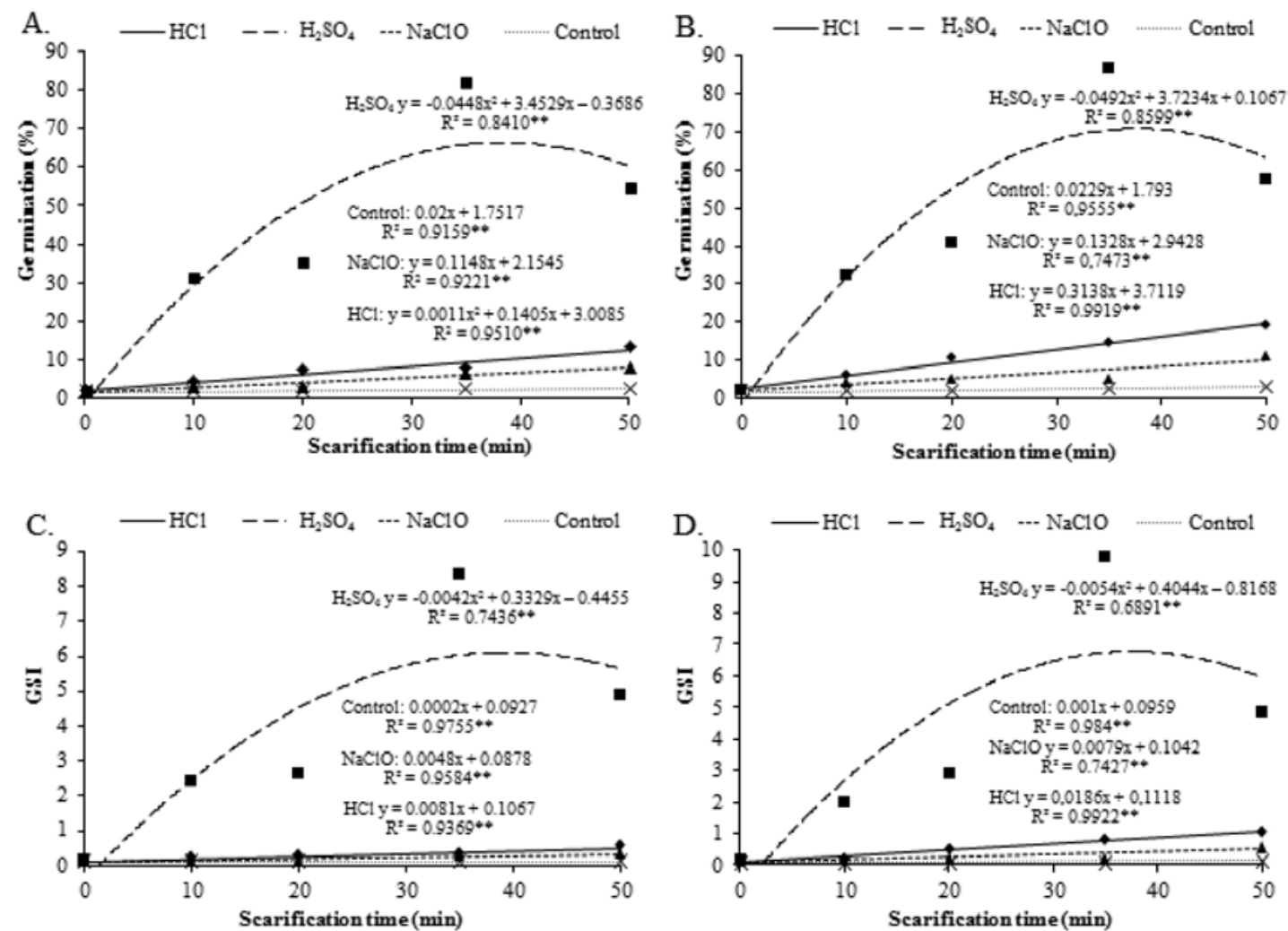

Figure I. Effect of chemical scarification by $\mathrm{NaClO}, \mathrm{HCl}$ and $\mathrm{H}_{2} \mathrm{SO}_{4}$ on germination percentage and germination speed index (GSI) of two batches of strawberry achenes Aromas cv. (Batch $1=\mathrm{A}$ and C, Batch $2=\mathrm{B}$ and D). ${ }^{* *}$ Significant at the $\mathrm{P}<0.01$ level. 
immersion with these solutions should be evaluated over longer periods to verify their real usefulness to break the dormancy of strawberry achenes. The GSI response was similar to germination in the $\mathrm{H}_{2} \mathrm{SO}_{4}$ treatment, where GSI increased to a maximum at 39 min scarification period (batch $1=7.04$ and batch $2=7.65$ - Figure I C. and D., respectively). Thus it was determined that treatment with $\mathrm{H}_{2} \mathrm{SO}_{4}$ is effective to enhance germination and GSI.

The dormancy break by chemical scarification in seeds with tegument dormancy is variable. Miller et al. (1992) evaluated the in vitro germination of strawberry achenes of (cv. Chandler x cv. Totem), treated with concentrated $\mathrm{HCl}$ for $15 \mathrm{~min}$, and observed maximum germination of $21 \%$; they concluded that this method was not effective to overcome dormancy. Wada \& Reed (2011) reported that germination of 17 species of Rubus seeds immersed in $\mathrm{NaClO}$ (14\% for $6 \mathrm{~h}$ ) and $\mathrm{H}_{2} \mathrm{~S}_{4}{ }_{4}(98 \%$ for $30 \mathrm{~min}$ ) increased compared to control, and treatment with $\mathrm{H}_{2} \mathrm{SO}_{4}$ was superior to $\mathrm{NaClO}$ in both germination percentage and germination speed.

In the second experiment more germination was observed between the times of 30 and $40 \mathrm{~min}$, therefore confirming the results obtained in the first experiment. The derivatives of the equations showed the maximum at $40 \mathrm{~min}$ (batch $1=89 \%$ and batch $2=92 \%$ - Figure II A.), and a possible decrease in germination at longer times, as seen in the first experiment.

Using the two experiments, $80 \%$ germination can be assumed as an average result of the immersion of achenes in $\mathrm{H}_{2} \mathrm{SO}_{4}$ for $40 \mathrm{~min}$. El Hamdouni et al. (2001) observed in vitro germination of $94 \%$ and $63 \%$ for Chandler and Tudla cultivars respectively when treated with $\mathrm{H}_{2} \mathrm{SO}_{4}(98 \%)$ for $5 \mathrm{~min}$. These results demonstrate that a shorter immersion time can provide a high rate of dormancy break, however, it is noteworthy that these rates were observed after 16 weeks of evaluation, which is a long period to overcome dormancy effectively and would increase the costs of the program. Ito et al. (2011) immersed strawberry achenes of 'Chiba F-1 go' in $\mathrm{H}_{2} \mathrm{SO}_{4}$ (98\%) for a period of 5 to $50 \mathrm{~min}$ and observed higher percentages of germination after 20 and 50 min treatment.

The application of $\mathrm{H}_{2} \mathrm{SO}_{4}$ to achenes promotes partial degradation of the pericarp, facilitating the absorption of water and inflow of oxygen to the embryo (Ito et al., 2011). Thus, as observed in this study, overcoming the physical barrier assists in enhancing germination. Although the immersion of achenes in $\mathrm{H}_{2} \mathrm{SO}_{4}$ can increase the speed and percentage of germination, the effect of time the of action should be studied, because as seen in this and other studies (El Hamdouni et al., 2001, Ito et al., 2011, Scoot \& Ink, 1948), excessive time is harmful, since there is probably penetration of acid reaching the embryo.

Although immersion of achenes in $\mathrm{NaClO}$ and $\mathrm{HCl}$ solutions increased germination, these treatments were not able to promote germination above $20 \%$. Furthermore, it is noteworthy that germination in $\mathrm{HCl}, \mathrm{NaClO}$ and control treatments occurred only at the seventh, eighth and tenth days after sowing (DAS) respectively, while the treatment with $\mathrm{H}_{2} \mathrm{SO}_{4}$ was at the third DAS (unpublished data). Therefore, achene treatment with $\mathrm{HCl}$ or $\mathrm{NaClO}$ is considered unsatisfactory for strawberry breeding, in terms of both germination percentage and germination speed.
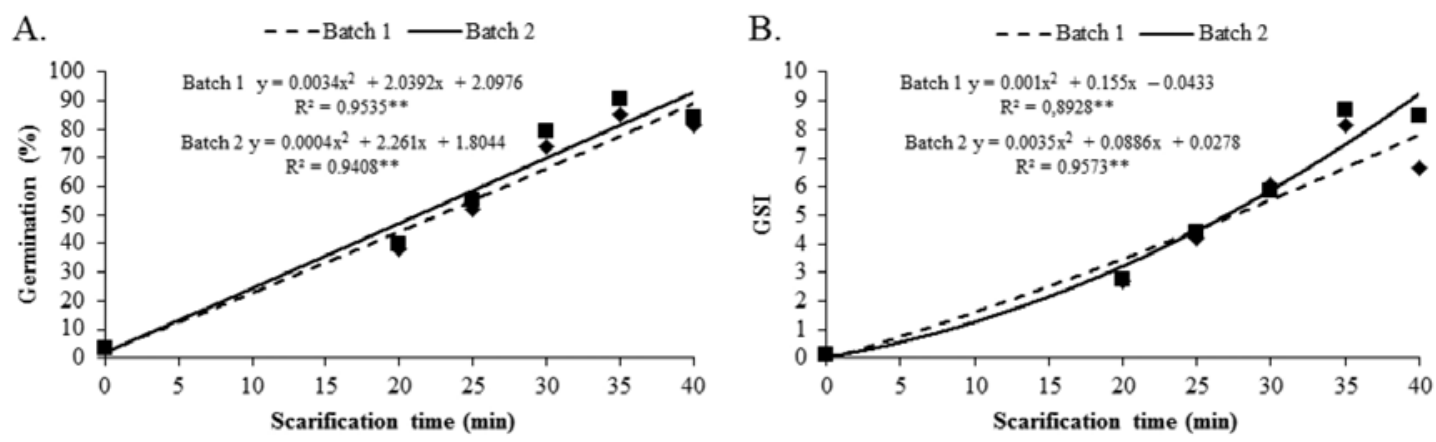

Figure II. Effect of chemical scarification with $\mathrm{H}_{2} \mathrm{SO}_{4}$ on the final germination percentage and germination speed index (GSI) of strawberry achenes Aromas cv. (A Germination and B GSI). ${ }^{* *}$ Significant at the $\mathrm{P}<0.01$ level. 
If we wish to produce strawberry seedlings without treatment to overcome dormancy $(10 \%$ germination) at least 300 fruits would be required (each fruit pollinated manually produces about 35 achenes) to obtain 1000-1100 seedlings. According to the University of Florida (UF), immersing achenes in concentrated $\mathrm{H}_{2} \mathrm{SO}_{4}$ for 15 min should obtain around 50\% germination (Chandler et al., 2012), thus 60 fruits would be needed to produce the same number of seedlings. By immersion of achenes in $\mathrm{H}_{2} \mathrm{SO}_{4}$ solution using method of this study ( $80 \%$ germination) 37.6 fruits would be needed, with an economy of $87.5 \%$ compared to no treatment and $37.3 \%$ in relation to the UF method. The UF uses typically 10000 seedlings to start a breeding program on strawberry. For this amount, 2858 fruits would be necessary without application of treatment, 572 fruits by the UF method and 358 fruits by the method of this study, meaning that 214 less fruits than the usual method of UF would be needed. This would reduce costs, because pollination in the programs is still performed manually.

\section{Conclusions}

Scarification with $\mathrm{H}_{2} \mathrm{SO}_{4}$ (98\%) for 40 min increases strawberry achene germination to $80 \%$ and can be used as a technique to overcome dormancy.

Scarification with $\mathrm{HCl}$ and $\mathrm{NaClO}$ increases germination and the GSI; however, other concentrations and immersion times should be studied to increase the efficiency of these methods.

\section{Acknowledgements}

To Capes for providing a scholarship to the first author and to UFLA for providing the structure needed for performing the experiments.

\section{Literature Cited}

Brasil. Ministério da Agricultura e Reforma Agrária. 1992. Regras para análise de sementes. Brasília: SNDA/ DNDV/CLAV, $365 \mathrm{p}$.

Chandler, C.K.; Folta, K.M; Dale, A.; Whitaker, V.M.; Herrington, M.E.

2012. Strawberry. In: Badenes, M.L.; Byrne, D.H (Org). Fruit breeding. New York: Springler, $1^{\text {a }}$ ed., pp. 305-325.

Durrant, M.J.; Mash, S J.; Payne, P.A.

1992. The use of hydrochloric acid to improve the germination of sugar-beet seed. Plant Growth Regulation, 11 (4): 363-369.

El Hamdouni, E.M.; Lamarti, A.; Badoc, A.

2001. In vitro germination of the achenes of strawberry (Fragaria x ananassa Duch.) cvs 'Chandler' and 'Tudla”. Bull. Soc. Pharm. Bordeaux,140: 31-42.

Erasmo, E.A.L.; Terra, M.A.; Domingos, V.D.; Martins, C.C.; Costa, N.V.

2008. Superação da dormência em sementes de Murdannia nudiflora (L.) Brenan. Acta Scientiarum. Agronomy, 30: 273-277.

FAO

Production/crops/strawberries. Disponible en: http://faostat3. fao.org/home/index.html\#DOWNLOAD. Consultado: $23 / \mathrm{Jan} / 2013$.

Folta, K.M.; Davis, T.M.

2006. Strawberry genes and genomics. Critical Reviews in Plant Sciences, 25 (5): 399-415.

Ito, Y.; Maruo, T.; Ishikawa, M.; Shinohara, Y

2011. Effects of scarification with sulfuric acid and matric priming on seed germination of seed propagation type of F-1 hybrid strawberry (Fragaria x ananassa Duch.). Journal of the Japanese Society for Horticultural Science, 80 (1): 32-37.
Maguire, J.D.

1962. Speed of germination aid in selection and evaluation for seedling emergence and vigor. Crop Science, 2: 176-177.

Mayer, A.M.; Poljakoff-Mayber, A.

1989. The germination of seeds. Oxford: Pergamon Press, $270 \mathrm{p}$.

Miller, A.R.; Chandler, C.K.

1990. Plant regeneration from excised cotyledons of mature strawberry achenes. Hortscience, 25 (5): 569-571.

Miller, A.R.; Scheerens, J.C.; Erb, P.S.; Chandler, C.K.

1992. Enhanced strawberry seed germination trough in vitro culture of cut achenes. Journal of the American Society for Horticultural Science, 117 (2): 313-316.

Nakamura, S.

1972. Germination of strawberry seeds. Journal of the Japanese Society for Horticultural Science, 41: 367-375.

Qin, Y.; Teixeira da Silva, J.A.; Zhang, L.; Zhang, S.

2008. Transgenic strawberry: State of the art for improved traits. Biotechnology Advances, 26 (3): 219-232.

Scoot, D.H.; Ink, D.P.

1948. Germination of strawberry seed as affected by scarification treatment with sulfuric acid. Proceedings of the American Society of Horticultural Science, 51: 299-300.

Thompson, P.A.

1969. The use of chiling and chemical treatments to promote rapid germination of strawberry achenes. Journal of the Horticultural Science, 44: 201-210.

Wada, S.; Reed, B.M.

2011. Standardizing germination protocols for diverse raspberry and blackberry species. Scientia Horticulturae, 132: $42-49$ 